\title{
The Russian oil industry between public and private governance: obstacles to international oil companies' investment strategies ${ }^{1}$
}

\author{
Research Fellow, CNRS \\ LEPII-EPE (formerly IEPE), University of Grenoble II, July 2004
}

Submitted to Energy Policy

The low level of involvement by international oil companies in Russia seems difficult to explain given what development of its resources and production has to offer. Since 1985, first under Mikhail Gorbachëv and then under Boris Yeltsin, the recourse to foreign investment has seen as one of the best means of financing a sector with considerable investment needs. Russia's aim of integrating itself into the world market also argues in favour of significant involvement by international oil companies in that country. Meanwhile, Russia has become a principal actor on the international oil market, with production levels of 8 million barrels per day (mbd) in 2003. As such, it has now become very important for the international oil companies, as access to resources in the major oil-producing countries of the Middle East remains closed. That, however, is as far as the consistency of interests goes; there are still many restrictions and contradictions, born of the particular institutional and political environment of the Russian oil industry at the end of fifteen years of transition, that act as a bar to international integration.

The reforms and privatisation programmes implemented have allowed new actors, largely independent of the State and its overall political objectives, to emerge. The industry has mainly restructured itself around these actors, who are national private firms tied into a complex network of domination and subordination with the Federal State and the Regions. These firms are not a homogeneous group, given the wide variety of their assets and the differing strategies arising in consequence. The Federal State and its government and administrative authorities do not have a united vision of the policy to be pursued and the type of control to be developed in relation to oil companies involved at national level. The Regions, faced with a weakened Federal State, are also interfering in the sharing of the hydrocarbon rent.

In this destabilised institutional environment, three factors currently define the establishment of relations with foreign investors. First, because of the many different levels of negotiation with Russian companies, the State and the Regions, the decisions are based on complex relations between the various forces. Second, the reforms, and especially privatisation and the allocation of rights of ownership to deposits, are considered by sizeable sections of public opinion and many political classes to be illegitimate, thus making the issue of international investment and foreign presence still more complicated. Finally, the State's wish to take back the oil industry in order to use it to fulfil its economic and foreign policies is creating further uncertainty. These three elements reduce the number of institutional and legal organisations likely to secure international investments, and seriously restricts the entry of international oil companies to the Russian market. It is in the context of this "hybrid" governance, both public and private, affecting the industry, that international oil companies' strategies need to be determined as far as Russia is concerned.

\footnotetext{
${ }^{1}$ We would like in particular to thank Dominique Finon for his comments and suggestions, which were a valuable contribution to the structure of this article.
} 
First, we will define the game being played between Russian companies and the State, marked by a new affirmation of public co-ordination. Second, we will analyse its effects on the noncompletion of the reorganisation process and the stabilisation of the new institutions. From that, we will deduce what possibilities there are for international companies to enter that game and involve themselves in it.

\section{1 - Investment stakes for the Russian oil industry}

To continue the long-term rise in Russian oil production requires considerable investment. The elements that triggered its growth in the early 2000s are now beginning to flag, and the renewal of mature deposits is suggesting that further exploratory efforts will be made in consequence. From this point of view, the "economic transition" has led to a significant drop in investment in exploration. This drop is one of the striking characteristics of the new Russian oil companies' strategies.

The structure of the industry has radically altered in comparison with the centralised, hierarchical and tightly controlled system administered by the Soviet Oil Ministry, but has not yet stabilised. As part of the "liberal" approach to the transition, developed by the Washington Consensus $^{2}$, the aim of oil industry reform was to produce a new organisational model based on various private enterprises. What was needed was to redefine the rights of ownership through huge privatisation programmes and to develop competition by breaking up the old hierarchies. The transposition of the industrial organisational model of the market economy oil industry has however been only partial. Because the oil rent has been controlled in order to supply the public budget while relying on income from exports, the Russian State has maintained control of the transport networks. In contrast to the Western companies, transportation has not been integrated into the vertical production and refining companies because of the wish to control export income ${ }^{3}$.

From the beginning of the 2000 s, most of the rise in Russian production has been attributable to investment in boosting production from existing fields ${ }^{4}$. The investment strategies developed in the 1990s allowed productivity to be increased, especially through using enhanced oil recovery techniques. Now, the future of Russian oil production depends mostly on large-scale recovery of the investments made in exploration. The AIE has assessed the

\footnotetext{
${ }^{2}$ According to G. Roland, the transition envisaged by the Washington Consensus is based on a combination of neo-classical price theory, standard macroeconomic theory and the experience of stabilisation policies. It is opposed to the more institutionalist view of the transition. For a presentation of the two views of the transition, the reader is referred in particular to: Roland (G.).- Transition and Economics : Politics, Markets, and Firms.The MIT Press, Cambridge, Massachusett, London, England, 2000, 400 p. et Andreff (W.).- La mutation des économies postsocialistes : Une analyse économique alternative.- L'Harmattan, collection Pays de l'Est, 2003, $366 \mathrm{p}$.

${ }^{3}$ Because of the magnitude of the investments to be made and the specific nature of the assets, this is traditionally included in the production and refining industry.

${ }^{4}$ More than half of the rise in production is attributable to three oil companies, namely Yukos, Sibneft and Surgutneftegaz. The first two companies have made huge investments in enhanced oil recovery techniques (hydrofracture, horizontal drilling etc). « World Energy Investment Outlook 2003 ».- AIE-OCDE, 2003, p. 148.
} 
total investment needing to be made in the oil industry at $\$ 328$ billion for the period 2001$2030^{5}$.

The exploration and renewal of reserves, which determine long-term developments in the field of production, have however been largely ignored until now. For example, investment in exploration dropped by some $60 \%$ between 1988 and 1994. This trend occurred again in 2001-3, with a 30\% drop in 2002 compared with 2001. Russian reserves are very significant ${ }^{6}$, but low exploration investment levels are leading some experts do voice serious misgivings. At the current pace of production, unless massive investment is made in exploration the total of proven reserves will be halved in the next ten years ${ }^{7}$. From this point of view, the growth model that underlies the development in this industry has not changed fundamentally in comparison with the Soviet era, despite the reforms implemented (privatisation and organisational reforms).

According to the Ministry of Defence, this could have serious consequences on production in the next ten years ${ }^{8}$. In particular, the limited volume of investment is begging questions on the beginning of production in new oil-bearing areas such as Eastern Siberia or the TimanPechora region, in the light of the exhaustion of the major Western Siberian basins. It is from this significant point of view that the "Russian Majors" have built up their reserves mainly through mergers and the acquisition of smaller oil companies".

\section{2 - Institutional environment and organisational model}

The lack of investment in oil exploration is linked with the unexpected result of the almost total privatisation of a structured industry into a private and poorly consolidated oligopoly, through an institutional environment notable for the weakness of the Rule of Law.

\subsection{The Russian oil oligopoly}

\footnotetext{
${ }^{5}$ In the document published in 2003 by the Russian Government on the Russian Energy Strategy, the required investment is totalled at $\$ 230-240$ billion for the period 2000-2020.

AIE-OCDE, 2003, op. cit., p. 144-146.

${ }^{6}$ They are however the subject of numerous disputes. According to BP, Russia's oil reserves total in the region of 60 billion barrels, while the USGS evaluation gives a figure of 207 billion barrels.

« Saudi Pact Shows Russia's New Strength ».- Petroleum Intelligence Weekly, 8 September 2003, p.1-2.

${ }^{7}$ Konoplyanik (A.).- « Is Oil production Crisis Imminent in Russia ? ».- Energy and Investment Policy and Project Financing Development Foundation, 2000, 5 p.

${ }^{8}$ Defense Minister Tries on Energy Hat".- The Moscow Times, 18 November 2003, 2 p.

The commentary by G. Khan, a director of TNK, published in Oil and Gas Journal, is particularly revealing from this point of view. He considers that many companies are operating mature deposits, many of which were damaged by Soviet-style management methods. For him, the future of the Russian oil industry is in the development of new areas in Eastern Siberia and the Far East. Most of the investment made is aimed at maintaining production from existing deposits. The $\$ 10,000$ million invested annually by the Russian oil companies will not be sufficient to develop any new major projects.

« TNK's Khan : PSA still crucial for Russian oil industry » .- Oil and Gas Journal, 10 March 2003, p. 33-35.

${ }^{9}$ Of the major Russian oil companies, only Lukoil has developed a strategy of investment in the exploration of new oil-bearing areas, mainly in the North Caspian area and the Timan-Pechora basin.
} 
The Russian oil industry is currently an oligopolistic industry structured around a small number of major industrial and financial groups. Four major private oil companies, namely Lukoil, Yukos, TNK (now TNK-BP) and Surgutneftegaz, provide $66 \%$ of production and $57 \%$ of exports. Most shares in the new companies are held by the Russian banks, with the exception of Rosneft', all of whose shares are held by the State. Its share in production is, however, relatively marginal, at a mere $3.8 \%$ (see Table 1). This concentration of the oil industry is the result of the huge merger movement in the late $1990 \mathrm{~s}$, which led to the acquisition of $100 \%$ control by Lukoil of KomiTek, $54.2 \%$ control of VNK by Yukos, equal shares of control over Slavneft by TNK and Sibneft, and control of Sidanko by TNK. The State's capacity for controlling production was limited by the weight of the private sector.

Table 1: The main Russian oil companies and the composition of their capital

\begin{tabular}{|c|c|c|c|c|c|c|c|c|}
\hline & & $\begin{array}{l}\text { Production } \\
\text { Mbd, } 2002\end{array}$ & $\begin{array}{c}\text { Export, } \\
\text { mbd, } 2002\end{array}$ & State & $\begin{array}{c}\text { "Outside" } \\
\text { Bank }\end{array}$ & $\begin{array}{c}\text { Financial } \\
\text { structures } \\
\text { and Bank } \\
\text { of the } \\
\text { holding }\end{array}$ & Others & $\begin{array}{c}\text { Inter- } \\
\text { national } \\
\text { investment }\end{array}$ \\
\hline \multirow{2}{*}{$\begin{array}{l}\text { Group } 1 \\
\text { Holding owns } \\
\text { the Bank }\end{array}$} & Lukoil & 1.5 & 0.69 & 7.6 & 9.0 & $41.0(1)$ & 15.4 & 26.3 \\
\hline & Surgutneftegaz & 0.99 & & 1.0 & - & $80.0(1)$ & 20.0 & - \\
\hline \multirow{5}{*}{$\begin{array}{l}\text { Group } 2 \\
\text { "Outside" bank }\end{array}$} & Sibneft (5) & 0.53 & 0.21 & 0.63 & 1.0 & $\begin{array}{c}\text { FNK (2): } \\
51.0 \\
\text { SINS (3): } \\
19.0\end{array}$ & 29.0 & - \\
\hline & $\begin{array}{l}\text { Sidanko } \\
\text { until } 2003\end{array}$ & 0.32 & & - & $\begin{array}{l}\text { Interros Oil } \\
\text { (4): } 40.0 \\
\text { Alfa Group } \\
\text { (AAR): } 24 \\
\end{array}$ & - & 11.0 & $25.0(\mathrm{BP})$ \\
\hline & $\begin{array}{ll}\text { Tyumen } & \text { Oil } \\
\text { Company } & \\
\text { Until } 2003 & \\
\end{array}$ & 0.76 & 0.34 & - & $\begin{array}{l}\text { Alfa Group } \\
\text { (AAR): } 50,2\end{array}$ & - & 49.8 & - \\
\hline & \multicolumn{8}{|c|}{$\begin{array}{l}\text { BP-TNK: created in 2003: joint venture in which BP and TNK each hold 50\% of the JV's shares. Production of } 1.19 \\
\text { mbd in } 2003(6)\end{array}$} \\
\hline & Yukos (5) & 1.4 & 0.73 & - & $\begin{array}{c}\text { Rosprom- } \\
\text { Menatep: } 85.0\end{array}$ & - & 29.0 & - \\
\hline \multirow{2}{*}{$\begin{array}{l}\text { Group } 3 \\
\text { Majority State } \\
\text { ownership }\end{array}$} & Rosneft & 0.29 & & 100.0 & - & - & - & - \\
\hline & $\begin{array}{l}\text { Slavneft } \\
\text { until } 2002(7)\end{array}$ & 0.30 & & 76.0 & - & - & - & - \\
\hline
\end{tabular}

Notes to table.

(1) Unlike other holding companies, the shares in Lukoil and Surgutneftegaz are held by banks created by the holding companies themselves.

(2) FNK is a subsidiary of the Logovaz Group.

(3) SINS is linked to Stolichny Bank Sberezhnii-Agro Bank.

(4) Interros Oil is a subsidiary of Uneximbank.

(5) Sibneft and Yukos merged in 2003. This merger is however purely theoretical at present and Sibneft is trying to have it annulled following Yukos's problems with the legal system.

(6) The JV also includes the shares in Sidanko held by BP (25\%) and TNK (40\% through the Alfa Group), as well as the shares held in Sibneft and Slavneft by TNK.

(7) At end 2002, the State's 76\% holding in Slavneft was sold 50\% to TNK and 50\% to Sibneft, namely two holding companies mostly held by the banks.

Sources: Locatelli, C., Transition Economique et Modèle d'Organisation Industrielle: Le Cas de l'Industrie Pétrolière Russe, Revue d'Économie Industrielle, No. 96, $3^{\text {rd }}$ quarter 2001, pp. 29-54. Reports on the various oil companies' activities.

These companies' strategies are characterised by two aims: maximised exports with guarantee of maximised unitary income higher than internal sales, and its corollary, the production maximisation. The considerable increase in oil production over the last two years (production of $7.1 \mathrm{mbd}$ in 2002 and $8.4 \mathrm{mbd}$ in 2003) has raised Russian export totals to $3.76 \mathrm{mbd}$ in 2003 
compared with $2.90 \mathrm{mbd}$ in 2000 (see Table 2), given that exports to Europe have always been high despite the fall in production between 1990 and 1998.

Table 2: Evolution of the Russian oil production and exportation, 1992-2003, Million of barrels per day

\begin{tabular}{|lccccccccccc|}
\hline & $\mathbf{1 9 9 2}$ & $\mathbf{1 9 9 3}$ & $\mathbf{1 9 9 4}$ & $\mathbf{1 9 9 5}$ & $\mathbf{1 9 9 6}$ & $\mathbf{1 9 9 7}$ & $\mathbf{1 9 9 8}$ & $\mathbf{1 9 9 9}$ & $\mathbf{2 0 0 0}$ & $\mathbf{2 0 0 1}$ & $\mathbf{2 0 0 3}$ \\
Production & $\mathbf{7 . 9}$ & $\mathbf{7 . 2}$ & $\mathbf{6 . 4}$ & $\mathbf{6 . 1}$ & $\mathbf{6 . 0}$ & $\mathbf{6 . 2}$ & $\mathbf{6 . 2}$ & $\mathbf{6 . 1}$ & $\mathbf{6 . 5}$ & $\mathbf{7 . 1}$ & $\mathbf{8 . 4}$ \\
Exportation & $\mathbf{2 . 7 6}$ & $\mathbf{2 . 4 6}$ & $\mathbf{2 . 6 1}$ & $\mathbf{2 . 4 6}$ & $\mathbf{2 . 5 2}$ & $\mathbf{2 . 5 5}$ & $\mathbf{2 . 7 5}$ & $\mathbf{2 . 7 0}$ & $\mathbf{2 . 9 0}$ & $\mathbf{3 . 2 3}$ & $\mathbf{3 . 7 6}$ \\
CIS & 1.44 & 0.86 & 0.77 & 0.53 & 0.41 & 0.34 & 0.39 & 0.38 & 0.34 & 0.47 & 0.76 \\
Outside CIS & 1.32 & 1.60 & 1.84 & 1.93 & 2.11 & 2.21 & 2.36 & 2.32 & 2.56 & 2.76 & 3.0 \\
\hline
\end{tabular}

Sources : Goskomstat, Moscow, several years, Russian Economy in 2001 : Trends and Outlooks.- Institute For The Economy in Transition, Moscow, several years.

These two objectives are part of a short-term strategy of seeking immediate liquidity through exports, with the aim of rapidly increasing the value of existing assets. This practice, known as cash stripping, is accompanied by the strategy of asset stripping, which for the most dynamic oil companies allows a rapid increase in the exportable production base through the acquisition of companies and their reserves without the need to embark upon huge exploration programmes that are less certain and much more costly in terms of investments. This shortterm behaviour is based on two factors: the financial rationality of the private groups who bought the assets of the state companies sold cheaply under the Yeltsin Government's Loan for Shares programme in $1995^{10}$ and the continuing uncertainty over ownerships rights to assets and resources.

\subsection{The non-completion of the sectorial institutions}

The conflicts that have marked the last ten years reveal a fragility and lack of credibility in the market institutions. Although the market institutions (business law, bankruptcy law, jurisdictions, the banking system etc) have been set up both generally and with regard to the oil industry (laws relating to resources, privatisation etc), this institutional environment is nowhere near able to guarantee ownerships rights and authorises arbitrary actions by public powers. The capacity of laws and legislation to regulate a profitable industry through credible market institutions is quite clearly low. In fact, three areas of uncertainty can be identified.

- First, the privatisation of hydrocarbons has led to uncertainty concerning one aspect of the private ownership right, the use of assets. The privatisation processes have mostly been seen as illegitimate, because of the serious lack of transparency under which they were conducted (purchase of shares at greatly reduced prices, absence of tender process, participation by banks in auctions that they organised and won themselves, and failure to realise the investments that the successful bidders were reckoned to be making in the

\footnotetext{
${ }^{10}$ This system of loans for shares gave the Russian banks three years of control over a portion of the shares held by the State in the capital of the oil holding companies, in return for government credit facilities. At the fixed due date, the State would have the right to take back the shares in return for repayment of the loans. Otherwise, the shares would have to be definitively repurchased through tender process.
} 
business ${ }^{11}$ ). The manipulation of bankruptcy law, linked to weakness of the Rule of Law (that is, the way in which the law is applied) moved the bankruptcy process out of its traditional role and turned it into a stripping process (the bankruptcy of Sidanko in 1999 is a classic example of this). In this context of illegitimacy, the State does not feel constrained to respect ownership rights, as is the case in the market economies; and it may decide to re-nationalise, with or without compensation. Now, in mid-2004, we should not exclude the possibility of Yukos being partly re-nationalised for the $40 \%$ of shares taken in 2003 and likely to be returned to the State to offset the company's tax debt. The State may also once again assume ownership of certain deposits sold hastily to public companies before privatisation. It could also alienate the right to transfer ownership of shares. In this way, when Yukos entered into discussions with Exxon-Mobil for the sale of $40 \%$ of its shares in 2003, the State blocked the transaction knowing that a transfer of strategic assets was about to be made to foreign partners, and that considerable enrichment for the owners of Yukos, which they acquired at a very low price in 1998, was at stake.

- Secondly, despite a legal framework based mainly on Western standards and practices, the practice of granting exploration and development licences is creating serious uncertainty over rights of access to Russian resources. Most of the licences held by the companies were not acquired under the system of tender, as is required by the law. This procedure could be justified by the need to adopt a pragmatic process that would allow a rapid reform of the hydrocarbon industry by granting a form of legal recognition to the exploitation of deposits granted de facto by the Soviet Union to the production associations, on the basis of which the holding companies were formed ${ }^{12}$. On the contrary, it demonstrates that transposing the most nearly complete institutional models from a market economy was not at all suited to the Russian environment in the early 1990s. Since 2001, on the basis of this "legal uncertainty", the Russian State has been reallocating a number of licences.

- Third, there is no single actor clearly defined and recognised as having power to allocate a legitimate and indisputable right of production and exploration to private companies. Licences to explore and develop the earth's resources are granted jointly by the Federal State and the regions. This has led to a number of conflicts between decision centres, marked by opposition between the State and the Regions but also, within the government, between the Ministries of Energy and Natural Resources.

\section{3 - Relations between the oil industry and the State}

The Russian Federal State is currently looking for a new model for regulating the oil industry in order to control its profits and guarantee its long-term future. Weakened by the disintegration of the Soviet State apparatus, it was compelled to accept the emergence of a strong regional power that involved itself in regulating the rent industries. The Russian State also wanted to privatise companies in the specific context of the economic transition and of relations between the political power and the new economic managers.

\footnotetext{
${ }^{11}$ Black (B.), Kraakman (R.), Tarassova (A.).- "Russian privatization and Corporate Governance : What Went Wrong ?".- Stanford Law Review, n 52, 2000, p. 1731-1808.

${ }^{12}$ Walde (T.).- Oil and Gas Legislation in Russia. From Texas To Siberia : Is a Russian Model Emerging ? .Centre For Petroleum and Mineral Law and Policy, University of Dundee, 1992, Professional Paper PP6, 17 p.
} 
The importance of the oil and gas rent and export income to the Federal budget and the financing of economic development has led the State to search for ways of rectifying the weakness of its institutional resources in order to control the use of the hydrocarbon rent. It has some problem to collect its tax revenue, and has trouble ensuring that the major industrial groups pay their taxes. Tax evasion is thus organised on a grand scale through offshore subsidiaries of oil companies established abroad, but also in "offshore zones" organised in some Russian regions, including Chukotka, Mordovia and Kalmykia ${ }^{13}$. In addition, the shortterm strategies of the private actors do not go well with a balanced long-term development of the industry or with the short-term aims of the Russian State. Faced with these two challenges, the State therefore finds itself confronted with a key question: what incentives should be introduced to direct the activities of oil companies towards long-term strategies instead of the current practices of asset stripping and cash stripping? Privatisation in an environment marked by the weakness of the market institutions has locked the oil industry on an institutional path that is undermining its long-term viability. The need, therefore, is to get out of this institutional blockage, and this explains the State's "taking back" process.

\subsection{The Federal State takes control again}

In the past, the response given consisted mainly of mastering information on income from exports and granting export rights. The State therefore remained the strongest link in the chain by retaining ownership of the export networks. It is in fact known that hydrocarbon exports to the European markets ensured that the Russian companies stayed profitable and made a major contribution to hard-currency income in the Russian economy. Thanks to its two national companies, Transneft for the crude oil pipelines and Transneftprodukt for the oil product pipelines, the State was able to define the export volumes for each company. In theory, there is a system of equality of access to the transport network for each company according to its production levels: each company is allowed to export $25 \%$ of its production. However, because of Russia's limited capacity for transportation and exportation, Transneft has set up an order or priority between companies for network access. In fact, the totals exported become a function of each company's capacity for negotiating with the State ${ }^{14}$. The tacitly adopted rule was the priority granted to the most powerful companies in terms of reserves, production and employment (Yukos and Lukoil). Through this quantitative type of regulation, the Russian State retained some control over equilibrium between companies. However, this regulation has limits, as was shown by the conflicts between the State and the Russian companies, which all through 2002 were talking about granting support to OPEP and about international oil prices.

In view of the economic growth objectives set forth by Vladimir Putin, and the scale of tax revenue from oil and gas companies in the State budget, it is essential for the government that international oil prices remain relatively high. According to the latest World Bank report, Russia's economic growth of about $7.3 \%$ in 2003 remains largely driven by hydrocarbon

\footnotetext{
${ }^{13}$ In addition, the government does not have the necessary information (especially on deposits) to set up a more efficient tax system taking account of the quality of deposits.

"The Benefits of Better Oil Sector Taxation".- The Moscow Times, 9 February 2004.

${ }^{14}$ The State has sometimes looked to use its power of allocation as a means of exerting pressure. As a means of compelling them to pay their tax arrears, some holding companies have been refused access to the Transneft transportation network.
} 
export and production. This sector represents over $25 \%$ of the $\mathrm{GDP}^{15}$. Russia's fiscal and economic situation depends closely on changes in oil prices. Falls in international oil prices will clearly damage the balance of trade and income from tax in Russia, and this in turn will affect the rate of growth of GDP. A $10 \%$ change in international oil prices will lead to a $3 \%$ change in tax revenue and an increase of $10 \%$ in oil prices will allow a further increase of $2.2 \%$ in $\mathrm{GDP}^{16}$.

This economic growth objective implies a new distribution of oil profits, which reflects the dramatic conflict between Yukos President Mr Khordokovsky and the government during $2003^{17}$. The political compromise reached in 2000 between Vladimir Putin and the oligarchies, under which the State secured private ownership rights under privatisation programmes in return for a less speculative approach and transparency in company management, has been blown to pieces. Having observed that the oil industry oligarchies have reinvested very little of the export revenue in the Russian economy, the State now intends to define a new compromise with three objectives in mind. First, part of the profits must be redistributed to consumers, in particular by keeping internal prices relatively low. Second, a significant portion of the oil profits must be used to modernise the Russian economy via its allocation to the State budget and industrial diversification of oil companies. The creation of a structure of industrial-financial groups, in a large part of industry as a whole, makes this strategy plausible. Finally, the companies need to raise the level of their investment in exploration, which has previously been forgone.

The State is therefore looking to increase its control over the industry indirectly, that is, without re-nationalising the oil industry on a grand scale ${ }^{18}$. It wishes to set up stricter control over hydrocarbon reserves; this should work against the Regions but favour companies benefiting from State support (Gazprom, Lukoil, Surgutneftegaz, Rosneft) ${ }^{19}$. It now intends to increase its control over export networks (and therefore limit as far as possible the construction of private pipelines that would be the property of the oil companies). It has put back in the saddle the companies in which it is the main shareholder, namely Rosneft for oil and Gazprom for gas ${ }^{20}$, thus indicating a real willingness to bring the hydrocarbons industry under the umbrella of economic development. This suggestion is borne out by the foreign policy of restoring Russia's place on the world scene through its oil power ${ }^{21}$. To do this, the

\footnotetext{
${ }^{15}$ This is a much higher figure than the $9 \%$ published by Goskomstat. « Russian Economic Report ».- World Bank, $\mathrm{n}^{\circ} 7$ February 2004, p.14

${ }^{16}$ Rautava (J.).- "The role of oil prices and the real exchange rate in Russia's economy".- Bank of Finland, Institute for Economies in Transition, BOFIT, 2002, Discussion Papers, n 3, $21 \mathrm{p}$.

17 “'Oligarchs Bow to Putin’s New Deal”.- The Moscow Times, 17 November 2003, 2 p.

${ }^{18}$ « Kremlin’s Hand Reshapes Oil Industry ».- Petroleum Intelligence Weekly, n 49, 8 December 2003, p. 1-2.

${ }^{19}$ Berniker (M.).-« Energy executives stand firm on Russia opportunities ».- Oil and Gas Journal, November 2003, p. 42-43.

In particular, the many special agreements negotiated by the regions during the Yeltsin presidency should be progressively undermined by the Putin government.
}

${ }^{20}$ On several occasions, the Russian State has reallocated development and exploration licences on a discretionary basis, in favour of the national companies Rosneft and Gazprom. The case of the Stokman deposit is an example of this.

21 “Russia Revising Great Game Rule Book”.- The Moscow Times, 15 April 2004, 4 p. 
government needs to gain control of developments in oil production and reserves, and to control export strategies, at the same time avoiding making a contribution to the reduction in international prices. The objective of maximising exports by Russian oil companies will be restricted and regulated by the State's macroeconomic objectives ${ }^{22}$.

\subsection{Interference by the Regions}

Too often overlooked by the analysts, the regions in which the major Russian hydrocarbon basins are located have an important role to play because of the weakening of the Central State and the laws adopted after the collapse of the Soviet Union. The first element that they influence is taxation. They also play a significant role in issues of employment protection and non-payment for products by insolvent industries. It is however in the allocation of licences for the exploration and development of hydrocarbon deposits that the weight and role of the regional powers is of undoubted importance. As in almost every country, the Russian Constitution grants ownership of underground resources to the Federal State. However, the development of onshore hydrocarbons in Russia depends on shared competence (in legal terms) between the Federal Government and the governments of the various regions in which the underground resources are located ${ }^{23}$.

The Subsoil Law, voted in 1992, defines the respective competence of the federal authorities and the regional powers ${ }^{24}$. The right to explore and produce is granted jointly by the Federal Government, represented by the minister for natural resources, and the regional powers, on the basis of sales by auction through invitation to tender ${ }^{25}$. For some deposits of local importance, they may be allocated by the regional authorities only ${ }^{26}$. The Subsoil Law provides that certain powers held by the Federal Government can sometimes be delegated to regional authorities on the basis of special agreements. This is reminiscent, in one sense, of the transfer of ownership of the underground from the Federal State with allocation of its exploitation to certain regions. The effect of this provision was the development of certain regional mining laws ${ }^{27}$, with internal opposition to federal legislation.

To sum up, the interests and strategies of the various actors in the Russian oil industry are not consistent. The interest of company owners in making the companies profitable in the short term are clearly opposed to the State's need to have stable tax revenue in the long term. In the same way, the assessment of the Federal State and the Regions of the oil industry's role in Russia's economic development and in regional development are not compatible. The goal of

\footnotetext{
${ }^{22}$ « Russia Leans Closer To Opec Goals ».- PIW, 5 January 2004, 2 p.

${ }^{23}$ The right to explore and develop the offshore hydrocarbons, conversely, is exclusively granted by the Federal Government.

${ }^{24}$ Two main laws manage the allocation of exploration and production rights in relation to offshore deposits: the Subsoil Law, adopted in 1992, and the 1995 law on production sharing agreements.

${ }^{25}$ There may be exceptions to this principle through direct negotiation.

Sheedy (J.).- « Energy/Natural Resources-Russia. Overview ».- August 2000, 5 p.

${ }^{26}$ Konoplyanik (A.).- « Concessions : from d'Arcy to Kozak ».- Oil, Gas and Energy Law Intelligence, vol I, $\mathrm{n}^{\circ} 1$, January $2003,11 \mathrm{p}$.

${ }^{27}$ We are looking in particular at the legislation of the Komi Republic and of the Khanty-Mansiisk Autonomous Okrug, two oil-rich regions in Tyumen' Province.
} 
maximising companies' exports and production is contrary to the interests of the State and the Russian economy when it leads to a drop in international oil prices ${ }^{28}$. The companies' shortterm views do not allow the long-term maintenance of high production levels, with corresponding budgetary and foreign currency income, to be envisaged. In the same way, the uncontrolled strategy of company restructuring can lead to economic and social instability in the regions. More generally, these restrictions raise the question of what will be the consequences of privatising a rent industry in an economy whose market institutions are embryonic and can easily be manipulated by the dominant interest groups.

\section{4 - Barriers to entry by international oil companies}

The role of international investment, and the opportunity for entry by foreign companies, has been reduced by developments in the Russian oil industry. The international oil companies are however showing considerable interest in Russia, strengthened by its recent increases in production. For its part, Russia is asserting its willingness to involve itself more closely in the international hydrocarbon industry. At the same time, it is emphasising the need for massive investment in the oil industry in order to modernise existing deposits and develop reserves, and this could constitute a basis for foreign companies entering. These two objectives could converge, justifying the lowering of barriers to entry by international companies.

International investments will however run up against an unstable economic environment with the distinctive feature of institutional and organisational opacity, a problem that those actively involved in the Russian industry often actually desire in order to preserve their interests (especially in relation to sharing the hydrocarbon rent). Foreign investment in the oil sector can take three forms. It may involve direct investment through acquiring a shareholding in the capital of Russian oil companies, the creation of a joint venture between a Russian company and a Western partner, or investment limited to exploration and development of a deposit through a Production Sharing Agreement. At present, international oil companies mainly become involved in the hydrocarbons market through the creation of joint ventures; the other forms of entry encounter serious obstacles.

International investment has now become a "competition" between the various actors on the Russian market. Despite recent partnerships and discussions, the conditions of access to resources for international companies are becoming harder, with a steep increase in the number of institutional restrictions.

\subsection{Heavily restricted entry}

Involvement by international oil companies in the Russian hydrocarbon industry usually takes the form of a joint venture with a Russian partner (generally a majority shareholder) in specific deposit exploration and development projects. The first joint ventures were created in 1989, after the 1986 law signed by Mikhail Gorbachëv laid down the legal basis for their creation. By the beginning of 2000 , there were about thirty such ventures ${ }^{29}$. The agreement signed in February 2003 between TNK and BP is greater than all the other experiments

\footnotetext{
${ }^{28}$ The oppositions and tensions that occasionally become apparent between the two groups of actors when OPEP has to be assisted in maintaining crude oil prices, especially through limiting of exports, are illustrations of this.

${ }^{29}$ Heinrich (A.), Kusznir (J.), Pleines (H.).- Investment and National Interests in the Russian Oil and Gas Industry“.-- Post-Communist Economies, Vol 14, n 4, 2002, p. 495-507.
} 
because it covers all the activities and deposits held by the Russian company. Foreign investment in the oil industry can also take two other forms.

Concerning these other forms of entry, it should be noted that the international investors were almost totally excluded from the mass privatisation in 1992 and later from Loans for Shares in 1995 (which allowed the companies' capital to be transferred to a number of oligarchies at greatly reduced prices). Not until 1997 were the restrictions on their participation in Russian companies' capital lifted ${ }^{30}$. With the exception of Sidanko, now in the TNK-BP joint venture, only Lukoil has a significant portion $(26 \%)$ of its capital held by foreign investors (see Table 2). An investment may also be limited to the exploration and development of a deposit through a "Production Sharing Agreement". Three major agreements have already been implemented in this way, namely Sakhalin I, Sakhalin II and the agreement concerning the Kharyaga Deposit ${ }^{31}$.

\section{- More and more institutional barriers}

Faced with the lack of stability and transparency in the conditions for granting exploration and development licences under the Subsoil Law regime, the Production Sharing Agreements regime offers legal guarantees in relation to taxation and, most importantly, to export network access. The "list law", a specific aspect of the Russian system, has already limited the scope of that law by stipulating that the grants could only relate to deposits shown on a list approved by the Duma. In addition, the fixing of transport tariffs and of conditions for access to the Transneft network still carried a heavy risk of arbitrariness. In fact, the rights of access to this network, from which international companies are assumed to benefit for oil covered by their production sharing agreements, are periodically contested.

The alteration in 2003 of the Production Sharing Agreements law, signed in 1995, made major changes to the conditions for accessing and developing resources ${ }^{32}$. In practice, use of the production sharing agreement is now becoming the exception. The criteria for defining deposits that can be covered by a production sharing agreement and as such are included in the "list law" have changed. The new law provides that use of a production sharing agreement is limited to those deposits for which no investors have declared themselves to be ready to

\footnotetext{
30 The restriction of participation by foreign investors in oil companies' shareholdings to $15 \%$, introduced in 1992, was lifted by the Decree of 4 November 1997.

A. Heinrich, J. Kusznir, H. Pleines, 2002, op. cit., p. 495-507.

31 The development of Sakhalin is the subject of two Production Sharing Agreements. Sakhalin I is run by Exxon-Mobil (30\%) and a number of Japanese companies grouped together in Sodeco (30\%), and from the Russian side by Sakhalinmorneftegaz-Shelf (23\%) and Rosneft (17\%). The Production Sharing Agreement was signed in 1996. The Sakhalin Energy Investment Consortium, responsible for developing Sakhalin II, consists of Shell (55\%), Mitsui (25\%) and Diamond Gas (20\%). There is no Russian partner. The Production Sharing Agreement was signed in June 1994. Finally, the Production Sharing Agreement for the Kharyaga Deposit (the Timan-Pechora Basin in the Nenets Autonomous Territory) was signed between the consortium consisting of Norsk Hydro, Total (the operator) and the Nenets Oil Company (held by the local authority) and Lukoil on the Russian side.

${ }^{32}$ Under the law, only $30 \%$ of Russian oil reserves can be developed under the production sharing agreements regime. In 2000, the 21 projects eligible for a production sharing agreement, and therefore included in the "list law", already accounted for $28 \%$ of Russian oil resources.

«High-level backing for PSAs».- Petroleum Economist, October 2000, p. 30. and «One Step Forward Two Back For PSAs in Russia ».- Petroleum Intelligence Weekly, 20 March 2000, p. 4.
} 
ensure development under the normal licence regime ${ }^{33}$. Because of this, the international oil companies are de facto compelled to operate within a strictly Russian legislative framework, either by creating a joint venture with a Russian company, as BP with TNK, or by entering the Russian companies' capital $^{34}$.

In addition, the international companies are running up against the institutional instability and lack of transparency in the system of allocation of exploration and development licences by the Federal State and the Regions. The arbitrary re-allocation of certain development licences by the State increases the country risk. The repeated refusal by the Russian Parliament and authorities to ratify and sign the Energy Charter, which was intended to make foreign investments secure, shows the lack of interest on the part of the Russian Government and the Regions in relation to entry by foreign investors.

\subsection{Conflict of interests between international companies and Russian actors}

The entry of international companies runs up against a number of perceptions and interests on the part of the State and the private oil companies. For the State, the control of the hydrocarbon rent and the conditions to have an access to the oil resources by foreign investors are crucial to the restoration of central power. It is an important geopolitical stake. The Russian companies, for their part, do not see any immediate interest in their arrival. They believe that they can reach the very optimistic production targets that they have fixed themselves for 2010 from existing deposits, with limited investment in improvement of techniques used. By that horizon, Yukos and TNK predict that Russian production will have risen to $11 \mathrm{mbd}$ compared with the current total of $8 \mathrm{mbd}$. The government is more prudent, the long-term energy plan that it approved in May 2003 providing for production of $9.4 \mathrm{mbd}$ in 2010; this figure will be easier to reach without significant involvement by Russian companies.

\section{- The nationalist perception of Russia's interests}

The Russian government's position is ambiguous in that it is looking to reconcile objectives that contradict each other: to consolidate Russia's credibility in relation to opening up to international capital and institutional reliability, while looking to preserve Russian interests alone. There is one overriding factor in its oil policy: to make it serve its economic objectives and foreign policy. From this point of view, the arrival of foreign investors could have a destabilising influence. It could be suggested that the coming of international oil companies would allow the increase in oil production to be continued while more effort is channelled into exploration, as the strategy of the new TNK-BP joint venture shows. The Russian government, however, is not necessarily in favour of a sudden significant increase in production, as it wishes to avoid excessive competition with that of OPEP export ${ }^{35}$. The largescale entry of foreign capital would make it more difficult to wield the control that the State intends restoring in this field. In particular, the foreign investors will attempt to free themselves from Transneft's transport monopoly, as TNK-BP has already announced, by

\footnotetext{
33 Bakoulev (P.).-« Dramatic Changes to Production-Sharing Regime ».- International Law Office, Energy/Natural Resources, August 2003,18, 3 p.

${ }^{34}$ Konoplyanik (A.).- « PSA debate not over yet ».- Petroleum Economist, July 2003, p. 12.

35 « Oil Output to Grow 11\% in’05 ».- The Moscow Times, 22 March 2004, 2 p.
} 
launching the installation of private export pipelines; this is quite clearly contrary to government perceptions.

It is therefore unlikely that the Russian State will favour significant penetration by foreign shareholders into the oil companies' capital ${ }^{36}$. This is not a new behaviour pattern, but the position adopted could be evolve to opening and real integration into the international oil industry through capital. It is also unlikely that agreements on the scale of the TNK-BP agreement could be a general model for integration. One thing, however, is sure: any major investment with international investor must now be approved by the Russian government, probably its highest level.

\section{- The conflicting interests of the Russian oil companies}

It is with reference to the uncertainty over ownership rights in the oil sector and to its current method of organisation that one can interpret the Russian companies' interests in seeing the international companies come in. The conditions likely to be acceptable to the Russian companies in relation to their interests will not be without effect on the methods and frameworks by which the international companies become involved.

\section{- $\quad$ The constraint of transparency in the production sharing agreements regime}

The conflict of interest is most obvious in relation to the system of production sharing agreements. For the foreign companies, the definition of a stable legal framework within the hydrocarbons industry, through a steady regime of production sharing agreements, has been and still is an essential condition for any large-scale and long-term undertaking in Russia. Conversely, a number of major Russian companies have lobbied determinedly against this law, leading, as we have already pointed out, to the recent alteration in conditions for granting agreements.

Their opposition to these agreements is born of their interest in maintaining a level of opacity in the way in which the industry works, in order to preserve the sharing of the hydrocarbon rent in their favour. In particular, this avoids any kind of legal arrangement that reveals more information and respects the tax rules, which would not allow partnerships with foreign operators. The weakness of the Rule of Law, which allows legal and fiscal regulations to be skirted around and market institutions to be manipulated, is something that the dominant figures on the market still want, insofar as the uncertainty and opacity in the institutional environment will allow them to preserve their gains ${ }^{37}$.

\footnotetext{
${ }^{36}$ This is illustrated by two striking examples. First, a Chinese oil company was excluded from the privatisation of Slavneft in early 2003, in favour of TNK and Sibneft. Second, the arrest of the President of Yukos in October 2003 suggests an anxiety to stop the draft agreement currently being discussed between Yukos and Exxon Mobil.

${ }^{37}$ Hoff (K.), Stiglitz (J.).- « After the Big Bang? Obstacles to the Emergence of the Rule of Law in PostCommunist Societies ».- World Bank Policy Research, Working Paper 2934, December 2002, 44 p.

This position is based on the critique of the argument developed by A. Shleifer and R. Vishny, according to which the creation of additional market institutions for the purpose of consolidating ownership rights would arise spontaneously from privatisation. According to these two writers, the new holders of rights of control over assets following an initial privatisation would have a strong incentive to encourage the definition of new legal regulations in order to guarantee their ownership rights.

Shleifer (A.), Vishny (R.).- The Grabbing Hand - Government Pathologies and their Cures.- Cambridges, MA : Harvard University Press, 1998.
} 
The organisation of industrial and financial holding companies that structure the oil industry shares and maintains this logic. The practice of internal transfer prices, which involves undervaluing the price of crude oil, is aimed at reducing the tax burden in the context of the single revenue-based $\operatorname{tax}^{38}$. By this means, it allows mining income to be distributed much more in favour of the Russian companies than would be allowed under the production sharing agreement system. This system would in fact require sales prices to revealed, thus providing a reference point for calculating tax and transparency in relation to investment procedures, use of underground resources, cost and taxation, which the Russian oil companies do not want ${ }^{39}$.

\section{- Partnerships in capital as a means of protecting ownership rights}

One could use the major entry efforts or the recent attempts in 2003 and 2004 to dispute the observation that the Russian companies are hostile to the arrival of international companies. The joint venture agreements (like TNK-BP) or the planned acquisitions, such as the ExxonYukos project in 2003 or the Total-Sibneft project in 2004 are responses to domestic political issues. Apart from their financial and technological capacities, the presence of international oil companies in their capital would be an effective means of limiting possible State intervention and thus reducing the risk of re-nationalisation of the oil industry. In this context, the international investments would be used to secure the ownership rights. At the same time, the wish for the energy industry to be taken back by the Federal State increases the company owners' incentives to rapidly increase the value of the assets held by them in the oil companies $^{40}$. Sale of part of the companies' capital at a valuation level without a measurement consistent with the price paid at the time of privatisation is much more effective than the export maximisation strategy ${ }^{41}$. In this perspective, there is consistency between the companies' strategic interests and the oligarchies' individual interests.

\section{- Interference from regional interests}

At present, the regions have only involved themselves in this debate by defining deposits that are eligible for a production sharing agreement and should thus be included in the List Law. This does not however mean that their position and interests do not count. In view of the key role of hydrocarbons in the industrial structure of some regions, especially Western Siberia (the Komi Republic and Timan-Pechora Region), it is evident that large-scale international investments could significantly alter the current states of equilibrium. The question of regional taxation is at the heart of the conflict with the international companies in the few production sharing agreements signed, as witnesses the example of Total over the Kharyaga Deposit in the Nenets Autonomous Region.

\footnotetext{
${ }^{38}$ This system is based on Mineral Resources Production. Konoplianik (A.).-« A struggle for Mineral Rent ».Petroleum Economist, September 2003, p. 23-24.

${ }^{39}$ Konoplyanik (A.).- « Would Russian oil companies really like to have a PSA regime in Russia ? ».- Oil and Gas Journal, 23 December 2003, p. 20-26.

40 The withdrawal of Abramovich from Russia's oil industry and aluminium industry illustrates this wish to rapidly increase the value of assets held. After selling a significant portion of his shares in Sibneft at the time of its merger with Yukos, he has now transferred 25\% of his shares in RusAl in favour of O. Deripaska. « Abramovich Sells 25\% of RusAl to Deripaska ».- The Moscow Times, 6 October 2003

${ }^{41}$ During the Loans for Shares programme, Mr Khodorkovsky acquired 78\% of Yukos for a mere $\$ 170$ million. He could transfer 40\% of Yukos' capital to Exxon Mobil for over $\$ 20$ billion. " Pipeline to power in Russia ».The Financial Times, 10-11 August 2003.
} 
To these issues should also be added that of preservation of employment, which obviously explains why the regions have often opposed the injection of foreign capital, especially during the privatisation movement. Faced with this issue, the regions are looking to preserve the status quo rather than to favour restructuring policies. The Russian companies are continuing to act as a "social regulator" in the exchange of tax advantages and the privileged granting of development and exploration licences. The involvement of foreign actors can only destabilise the existing agreements.

\section{5 - Conclusion}

It is important, for the long-term future of the Russian oil industry, for the new practices aimed at long-term strategies of investment in exploration and production to be affirmed. It is therefore essential for the institutional factors behind the practices of cash stripping and asset stripping to be weakened and for practices ordinary to American and European companies to take over from the current investment strategies for restoration of existing deposits. It seems that it will have to pass through restoration of control and co-ordination by the public authority. In this framework, the place that could be taken by the foreign companies in the Russian national oil industry is an unknown figure. In addition to technological, financial resources, the international oil companies could standardise the behaviour of the Russian companies involved and bring about consolidation of ownership rights. At present, privatisation alone has not been sufficient to bring about this consolidation and increased security. The major private "actors" have been more willing to preserve the "institutional opacity" in order to increase their share in the hydrocarbon rent.

The State's attempt to take back control of the oil industry is in fact a new and significant factor in the development of the oil industry, as it may lead to more controlled development of oil production and exports. The recent creation of the hybrid form of public and private governance can be seen as an effort to escape from the institutional blockage into which privatisation has forced the industry. However, it has been, and is still being, introduced at a price: the destabilising of the credibility of the Russian institutional environment, with use of the legal system by the government to destabilise the main company Yukos in 2003 and 2004 in order to bring in an alternative shareholding control of that company.

The "Russian risk" remains significant for international oil companies, despite the step forward made through the creation of the TNK-BP joint venture. The recent situation does not suggest that developments will be very favourable for international investors, despite Russia's wish for opening and international involvement as voiced by the Putin Presidency. It does not exclude the few selective large-scale agreements made under conditions laid down by the presidency. This type of government can however only limit participation by foreign investors in the Russian companies' capital and in the development of production assets.

\section{Bibliography}

Abramovich Sells 25\% of RusAl to Deripaska ».- The Moscow Times, 6 October 2003.

Andreff (W.).- La mutation des économies postsocialistes : Une analyse économique alternative.- L'Harmattan, collection Pays de l'Est, 2003, 366 p.

Bakoulev (P.).-« Dramatic Changes to Production-Sharing Regime ».- International Law Office, Energy/Natural Resources, August 2003,18, 3 p. 
Berniker (M.).-« Energy executives stand firm on Russia opportunities ».- Oil and Gas Journal, November 2003, p. $42-43$.

Black (B.), Kraakman (R.), Tarassova (A.).- "Russian privatization and Corporate Governance : What Went Wrong ?".- Stanford Law Review, n ${ }^{\circ}$ 2, 2000, p. 1731-1808.

« Defense Minister Tries on Energy Hat ».- The Moscow Times, 18 November 2003, 2 p.

Fontaine (J-M), Laherrère (J.), Perrodon (A.).- «Le rebond de la production pétrolière en Russie : quelles perspectives à long terme ? Quelles opportunités industrielles? ».- Revue de l'Energie, $\mathrm{n}^{\circ} 538$, July-August 2002 , p. $421-432$.

Goskomstat, Moscow, Several years

Heinrich (A.), Kusznir (J.), Pleines (H.).- Investment and National Interests in the Russian Oil and Gas Industry“.-- Post-Communist Economies, Vol 14, n 4, 2002, p. 495-507.

«High-level backing for PSAs ».- Petroleum Economist, October 2000, p. 30.

Hoff (K.), Stiglitz (J.).- "After the Big Bang? Obstacles to the Emergence of the Rule of Law in PostCommunist Societies ».- World Bank Policy Research, Working Paper 2934, December 2002, 44 p.

Konoplyanik (A.).- « Would Russian oil companies really like to have a PSA regime in Russia ? ».- Oil and Gas Journal, 23 December 2003, p. 20-26.

Konoplianik (A.).-« A struggle for Mineral Rent ».- Petroleum Economist, September 2003, p. 23-24.

Konoplyanik (A.).- «PSA debate not over yet ».- Petroleum Economist, July 2003, p. 12.

Konoplyanik (A.).- « Concessions : from d'Arcy to Kozak ».- Oil, Gas and Energy Law Intelligence, vol I, n 1 , January $2003,11 \mathrm{p}$.

Konoplyanik (A.).- «Is Oil production Crisis Imminent in Russia?».- Energy and Investment Policy and Project Financing Development Foundation, 2000, 5 p.

« Kremlin’s Hand Reshapes Oil Industry ».- Petroleum Intelligence Weekly, n 49, 8 December 2003, p. 1-2.

Locatelli (C.).- "Transition Economique et Modèle d'Organisation Industrielle : Le Cas de l'Industrie Pétrolière Russe".- Revue d'Economie Industrielle, n 96, 3ème trimestre 2001, p. 29-54.

« Oil Output to Grow 11\% in'05 ».- The Moscow Times, 22 March 2004, 2 p.

« Oligarchs Bow to Putin's New Deal ».- The Moscow Times, 17 November 2003, 2 p.

« One Step Forward Two Back For PSAs in Russia »-- Petroleum Intelligence Weekly, 20 March 2000, p. 4.

« Pipeline to power in Russia ».- The Financial Times, 10-11 August 2003.

Rautava (J.).- "The role of oil prices and the real exchange rate in Russia's economy".- Bank of Finland, Institute for Economies in Transition, BOFIT, 2002, Discussion Papers, $\mathrm{n}^{\circ}$ 3, 21 p.

Roland (G.).- Transition and Economics: Politics, Markets, and Firms.- The MIT Press, Cambridge, Massachusett, London, England, 2000, 400 p.

« Russian Economy : Trends and Perspectives ». Institute for The Economy in Transition, Monthly Bulletin, July and September 2003.

« Russian Economic Report ».- World Bank, n 7 February 2004, p. 4 
Russian Economy : Trends and Outlooks.- Institute For The Economy in Transition, Moscow, Several Years. « Russia Leans Closer To Opec Goals ».- PIW, 5 January 2004, 2 p.

“Russia Revising Great Game Rule Book".- The Moscow Times, 15 April 2004, 4 p.

« Saudi Pact Shows Russia’s New Strength ».- Petroleum Intelligence Weekly, 8 September 2003, p.1-2.

Sheedy (J.).- « Energy/Natural Resources-Russia. Overview ».-, August 2000, 5 p.

Shleifer (A.), Vishny (R.).- The Grabbing Hand - Government Pathologies and their Cures.- Cambridges, MA : Harvard University Press, 1998.

Statistical Review of World Energy, 2002, BP/Amoco, June 2003

«The Benefits of Better Oil Sector Taxation ».- The Moscow Times, 9 February 2004.

«TNK's Khan : PSA still crucial for Russian oil industry ».- Oil and Gas Journal, 10 March 2003, p. 33-35.

Walde (T.).- Oil and Gas Legislation in Russia. From Texas To Siberia : Is a Russian Model Emerging? .Centre For Petroleum and Mineral Law and Policy, University of Dundee, 1992, Professional Paper PP6, 17 p.

« World Energy Investment Outlook 2003 ».- AIE-OCDE, 2003, p. 148. 